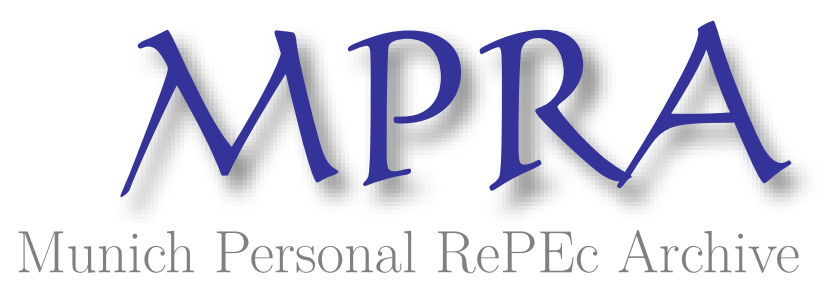

\title{
Shifting cultivation and forest pressure in Cameroon
}

Ickowitz, Amy

Center for International Forestry Research

2011

Online at https://mpra.ub.uni-muenchen.de/53077/

MPRA Paper No. 53077, posted 21 Jan 2014 05:04 UTC 


\section{Shifting cultivation and forest pressure in Cameroon}

Amy Ickowitz ${ }^{1}$

Abstract: Shifting cultivation is often blamed as a principal cause of deforestation in tropical Africa. It is claimed that the practice is unsustainable because shortened fallow lengths result in soils too degraded to support forest vegetation. The decline in fallow lengths is often attributed to increases in population density and greater market participation. The conventional wisdom makes several claims that are as yet unsubstantiated. This paper investigates whether there is evidence to support two of these claims in southern Cameroon. First, using both cross-sectional and panel data, I find that there is indeed a robust negative association between fallow lengths and population density in the study area and weaker evidence for a negative relationship between fallow lengths and market participation. Second, a stochastic frontier production function approach is used to investigate the marginal contribution of fallow to output. Results indicate that fallow lengths are not low enough to be affecting yields and therefore do not appear to be resulting in declines in soil fertility. Thus overall, while some of the assumptions of the conventional wisdom appear to be true, there is little evidence to support its dramatic conclusion that shifting cultivators are causing deforestation in the forested region of Cameroon.

Keywords: Shifting cultivation, population density, market participation, deforestation, Cameroon JEL Codes: 012;013;Q01;Q12

This is a pre-copyedited, author-produced PDF of an article accepted for publication in Agricultural Economics following peer review. The definitive publisher-authenticated version [Ickowitz, A. "Shifting cultivation and forest pressure in Cameroon," Agricultural Economics, March 2011, vol. 42(2): 207-220.] is available online at: [http://onlinelibrary.wiley.com/doi/10.1111/j.15740862.2010.00507.x/abstract].

\footnotetext{
${ }^{1}$ Department of Economics, Clark University 950 Main Street Worcester, MA 01610

Phone: 508-793-7281

Fax: 508-793-9949

email: aickowitz@clarku.edu
} 


\section{Shifting cultivation and forest pressure in Cameroon:}

\section{Introduction}

Shifting cultivation ${ }^{2}$ is the dominant agricultural system in the humid tropics (Jepma, 1995; Hassan et al., 2005). It is a farming system that involves cycles of cropping and fallow periods. ${ }^{3}$ The fallow period allows the soil to regenerate and recover the nutrients depleted during the cropping phase. There have been numerous claims that shifting cultivators have reduced their fallow periods in most parts of tropical Africa to unsustainable levels (Amelung and Diehl, 1992; Kotto-Same et al., 1997; Lanly, 1982; Myers, 1992; Sunderlin and Pokam, 2002). The conventional narrative is that fallow periods are too low to allow for adequate soil fertility regeneration resulting in soil degradation which in turn can lead to deforestation.

Fallow lengths, it is claimed, have declined primarily due to increases in population densities and more extensive market participation (Aweto and Iyanda, 2003; Banful et al., 2007; Degrande, 2001; Kotto-Same et al., 1997; Ngobo et al., 2004; Sivakumar and Valentin, 1997; Szott et al., 1999; Tinker et al., 1996). These processes, it is argued, push farmers to use their land more intensively in order to produce more output either to feed larger populations or to sell in markets; since many farmers in sub-Saharan Africa do not use fertilizers, this entails using shorter fallow lengths. Shorter fallow periods can cause a reduction in organic matter resulting in a loss of soil nutrients and greater weed pressure (Juo and Manu, 1996; Nye and Greenland, 1960). The combination of reduced soil fertility and greater weed intensity is believed to reduce yields (Banful et al., 2007; Brady, 1996; Degrande, 2001; Mertz, 2002) pushing farmers to clear more forests to compensate for the decline in

\footnotetext{
${ }^{2}$ The terms shifting cultivation, slash-and-burn agriculture, and swidden cultivations are often used interchangeably in the literature (Kleinman et al., 1995; Tinker et al., 1996; Thrupp et al., 1997).

${ }^{3}$ Some scholars define any system of alternating cropping and fallowing cycles as shifting cultivation. Ruthenberg (1980) distinguishes between shifting cultivation and fallow systems by the total amount of annual cultivated land used out of the total available land. If more than $33 \%$ of land is used annually in cultivation, he defines the land use as a fallow system as opposed to shifting cultivation.
} 
yields on their old plots (Angelsen and Kaimowitz, 2001; Degrande, 2001; Tinker et al., 1996). ${ }^{4}$

Deforestation ensues when the decline in fertility is so severe that the soil becomes incapable of supporting forest vegetation and only scrub woodland or savanna grasses regenerate (Albers and Goldbach, 2000; Kotto-Same et al., 1997; Nye and Greenland, 1960; Sivakumar and Valentin, 1997; Tinker et al., 1996). Angelsen and Kaimowitz (2001) refer to this scenario as the 'land-degradation deforestation' hypothesis.

There is, however, little direct evidence that fallow lengths have in fact declined in any region of tropical Africa (Ickowitz, 2006). The main problem in trying to make the case for declining fallow lengths is that there exist few panel datasets on fallow periods for households in tropical Africa. ${ }^{5}$ In addition, while the commonly-cited narrative is intuitively plausible, its theoretical underpinnings are weak. If a farmer optimizes by choosing a fallow period to maximize the present value of her discounted utility, choosing a lower fallow period today will have effects on productivity in the future. Thus there will be both costs and benefits to shortening fallow periods in a dynamic context, the net result of which is not necessarily straightforward. This paper looks at the empirical evidence in support of the claims that shifting cultivation is resulting in deforestation through a decline in fallow periods in southern Cameroon.

Cameroon lies in the Congo Basin, an area that contains the second largest tropical rainforest in the world after the Amazon (Talbott, 1993). Sunderlin et al. (2000) claim that the deforestation rate in Cameroon is one of the highest in Central Africa. Thiele and Wiebelt (1994) attribute 90\% of

\footnotetext{
${ }^{4}$ While many scholars appear to equate this increased clearing of land with deforestation (Degrande, 2001; KottoSame et al., 1997; Mertens et al., 2000; Myers, 1992), technically, this is not necessarily the case. Since 'deforestation' is defined as permanent forest loss (FAO, 2001), it is possible that if the farmers leave the newly cleared plots for a long enough period of time after cultivation, the forest will re-grow. In practice, however, the plots usually enter the crop-fallow cycle so that the vegetation is cut once again before reaching forest maturity. ${ }^{5}$ The one study that I am aware of that has panel data for fallow periods in the region is by Mertens et al. (2000) in southern Cameroon. They construct a panel for fallow lengths based on recall data. There is no change in mean fallow periods between 1985 and 1997 for their sample of households. The focus of their study is not an examination of fallow periods, however, so they do not analyze its determinants or variability across space or time. Part of their dataset will be used in this paper.
} 
Cameroonian deforestation to agriculture which they claim is mainly carried out by shifting cultivation. Mertens et al. (2000) integrate data from a 1998 household survey with remote sensing images from the Eastern province of Cameroon for 1973 to 1996 and found high and accelerating rates of deforestation which they attribute to shifting cultivation. Thus it would appear that Cameroon is as a good a place as any in which to examine the links between shifting cultivation and deforestation.

This paper uses a panel dataset consisting of over 300 households in southern Cameroon to investigate two hypotheses implied by the narrative of declining fallow lengths and land degradationdeforestation in this region. The first hypothesis suggests that there should be negative associations both between fallow periods and population pressure and between fallow periods and market participation. These relationships are examined both cross-sectionally and over time using a variety of econometric specifications. A second hypothesis implied by the conventional wisdom is that since fallows are argued to have become too short to allow adequate soil fertility replenishment, fallow should be a constraining input on production. The evidence to support this hypothesis is investigated by an estimation of the marginal contribution of fallow on output though various specifications of a stochastic frontier agricultural production function. The results from the empirical analysis provide relatively strong evidence for the negative association between fallow and population pressure, weaker evidence for the relationship between fallow and market participation, and no evidence that fallow periods are so low as to be causing degradation-induced deforestation.

The remainder of the paper is structured as follows. Section II presents a brief overview of the relevant theoretical literature that focuses on a farmer's fallow response to changes in population density and prices. Section III offers some background of the study area and Section IV describes the data. The estimation strategies and results for the first hypothesis regarding the empirical relationships between fallow periods and population pressure and market participation are presented in Section V. 
The empirical investigation of the second hypothesis is presented in Section VI. And finally Section VII concludes.

\section{Theoretical Literature: Optimal Fallow Periods, Population Density, and Prices}

The theoretical literature on the relationship between fallow periods and population goes back over four decades to the work of Ester Boserup (1965). Boserup argued that increases in population density in developing countries would not result in population growth outstripping food production as neoMalthusians predicted. Instead, she pointed out that historically, humans found ways to support larger populations through innovation and by substituting labor for land in agricultural production. They have been able to shorten fallow periods without sacrificing agricultural production by finding ways to enhance soil fertility and by engaging in labor-intensive activities such as weeding and irrigation. Although her theory was not about deforestation per se, its implication is that while there would likely exist a negative association between population density and fallow lengths, this does not automatically imply that a reduction in fallow periods would result in declines in soil fertility.

More recent theoretical contributions formally model shifting cultivator behavior to examine fallow responses of a farmer to a change in the price of the good produced. ${ }^{6}$ An increase in the price of the good is argued to proxy for an increase in demand caused by population increase (Krautkraemer, 1994). This increase in price can also be seen as an incentive for greater market participation. Barrett (1991) uses a dynamic model to examine optimal cropping and fallowing responses to an exogenous change in the price of the agricultural good. Barrett's farmer's problem is to maximize the present value flow of net profits which depend only on soil fertility which he assumes

\footnotetext{
${ }^{6}$ There are several other papers that model shifting cultvators' responses to changes in population or price under the assumption of common property rights regimes (Ahuja, 1998; López 1998; Pascual and Barbier, 2006). This assumption changes the modeling framework substantially and does not hold for the region examined in this paper so these papers are not reviewed here.
} 
declines at a constant rate when the land is used for production. He finds that an increase in the price of the good does not have an effect on the optimal cropping or fallow periods.

Krautkraemer (1994) builds on Barrett's model, but assumes that profits are non-convex. This can most intuitively be thought of as having a fixed cost in production. He shows that when the net benefit function is non-convex, increases in the price of the agricultural good can lead to an increase in optimal cropping frequency (i.e., shorter fallow periods). The increase in price effectively reduces the importance of the fixed cost making it more attractive to the farmer to crop more frequently. If the increase in price is indeed a good proxy for increases in population density, then he has rigorously corroborated Boserup's argument.

Bulte and van Soest (1999) use an agricultural household model to look at the connection between the price of an agricultural good and soil erosion. Although this is a slightly different question, their basic model can be reinterpreted to apply to soil fertility depletion and thus to apply to a shifting cultivator household. While output in Barrett (1991) and Krautkraemer (1994) is only a function of soil quality, Bulte and van Soest (1999) assume that output is a function of both soil characteristics and labor. They find that in the case of complete markets, the household responds to an increase in price by increasing soil conservation (increasing fallow periods), but when there is a market failure for labor, the impact of the price change is indeterminant.

Based on the existing literature, we have several different theoretically plausible responses of optimal fallow lengths (or soil fertility) to an increase in the price of the agricultural good. In Barrett's model, there is no change in fallow; in Krautkraemer's model, the fallow period decreases; and in Bulte and van Soest's model, the soil fertility either increases (this is analogous to an increase in the fallow period) or is indeterminant. Thus the theoretical literature does not unambiguously support the commonly-held view that increases in population and increased market participation will inevitably 
result in shorter fallow periods and thus greater deforestation. Determining whether these relationships hold in reality can only be done by examining empirical evidence. The rest of this paper explores these relationships empirically using data from southern Cameroon.

\section{Background of Study Area}

The data used in this study are from 365 households in 49 villages in three provinces of southern Cameroon. Figure 1 is a map showing the location of the villages.

\section{(Insert figure 1 here)}

All villages in the Center and South provinces are represented by one dot, but the villages in the East are so close together that they are divided into two larger groups each represented by a single dot.

Property rights to land that has already been cultivated in this region are private and heritable, although rarely formal. While the state is the official owner of uncultivated forest and allows cultivation up to $6 \mathrm{~km}$ from the village boundary into the forest, it is usually the local chief who must grant permission to a village member to clear a new forest field that has not been cultivated in living memory. Once a field has been cleared by a farmer, it is recognized as his (women do not normally clear fields) private property. Chemical fertilizers and manure are rarely used so that farmers rely almost exclusively on the natural regenerative capacity of the soil for fertility. Most farmers divide their fields into three categories: food crop fields (cassava, peanuts, taro, sweet potato, and corn), forest crop fields (plantain, banana, cocoyam, and egusi melon) and cash crop fields (coffee and cocoa). This study focuses only on production in food crop fields. ${ }^{7}$

\section{Data}

\footnotetext{
${ }^{7}$ Cash crop fields are not farmed using shifting cultivation. Both food crop and forest crop fields are farmed using shifting cultivation, but the technologies in terms of the combination of soil fertility, labor, and land are quite different. Since part of the objective of this study is to estimate a production function, the two types of fields are not combined in the analysis because they are likely characterized by different production functions.
} 
The data used in this study consist of an unbalanced panel of 365 households that were surveyed in 1998 and 2001. The 1998 survey not only asked questions for the previous agricultural season, but also collected recall data for the years 1993 and 1985. The data for the first wave were collected by the Center for International Forestry Research (CIFOR) as part of two larger surveys conducted in 1998. The data from the second wave of the panel were collected by the author. In the second wave, 365 households that were surveyed in the first wave were re-surveyed. ${ }^{8}$ The empirical analysis which follows uses data from the second wave for a series of cross-sectional investigations and then examines changes in fallowing behavior over time by using data from both waves of the panel.

Table 1 presents some descriptive statistics from the data.

\section{(Insert table 1 here)}

Several of the variables warrant some explanation. The average fallow length ${ }^{9}$ reported in row 1 includes both fields that were cleared from old fallows with a maximum allowed fallow length of 20 years ${ }^{10}$ as well as fields cleared from forests that had not been farmed in living memory. Fields that were cleared from forest were assigned the maximum fallow length of 20 years. If we are concerned

\footnotetext{
${ }^{8}$ The first original CIFOR survey was conducted in the East province where 552 households were randomly selected in 33 villages. In the second CIFOR survey, 4078 households were surveyed in the South and Center provinces. In the second wave of the panel, half of the households originally surveyed by CIFOR in the East province were randomly selected in 23 of the villages (except in Ndélélé where one quarter of the original households were randomly chosen to prevent overrepresentation since it was by far the largest of the villages). All but two of the original villages in the South Province were included and 16 out of the 30 villages in the Center Province were included with a concentration on the villages that were in the forest belt.

${ }^{9}$ The fallow period was determined for each field that the farmer was currently farming by the response to the following question: 'how long had this particular field been left in fallow before you cleared it to farm this year?' Farmers in this region (Banful et al., 2007) do not usually actively farm a plot for longer than one year. Thus the cultivation intensity with respect to the cropping cycle is usually one year and therefore constant across the sample. ${ }^{10}$ If a respondent reported a fallow length of above 20 years, the fallow period is counted as 20 years for two reasons. First, it is hard to trust someone's memory for the distant past; i.e., can we really believe that someone remembers the difference between a field that was farmed 23 years or 28 years ago? Second, since the issue of concern is soil regeneration, we can assume that there is little difference in enhanced soil quality between a field that was in fallow for 20 years and one that was in fallow for longer due to diminishing marginal productivity of soil regeneration.
} 
with soil degradation resulting from inadequate fallow lengths, then since farmers who clear fields from forest are obviously allowing adequate soil regeneration, it is important to include these fields in the analysis. The first wave of the panel only provides information on fields cleared from older fallows. The average fallow length reported in row 2 includes only fields that were cleared form older fallows with a maximum allowed fallow length of 20 years (see footnote 12). All regressions that follow will use both definitions of fallow. The first wave of the survey asked farmers for the fallow period of the food crops that they had cultivated the past year (1997) as well as to recall the fallow periods of the crops that they had cultivated in 1985 and 1993.

The average fallow period in the sample appears to have actually risen over the entire time period under investigation. It is important to note, however, that the sample sizes are not the same across the sub-periods since all households did not cultivate continuously over the entire 16-year period and not all who did recalled their earlier fallow periods. T-tests for mean equivalence across the different sub-samples indicate that the average fallow period remained the same between 1985 and 1993, declined slightly between 1993 and 1997, but then increased between 1997 and 2001. ${ }^{11}$ The conventional wisdom of declining average fallow periods over the last few decades does not appear to hold in this area. While this is interesting in itself, it does not necessarily imply that there have not been reductions in fallow periods in areas with higher population pressure or greater market participation.

Village level data on population densities were not available for some villages and were not comparable for those that did have information since those counted in censuses were not consistent

\footnotetext{
${ }^{11}$ T-tests fail to reject the null hypothesis that the average fallow period was the same between 1985 and 1993, but reject the hypothesis that it was the same between 1985 and 1997 at the $95 \%$ confidence level indicating that they slightly decreased over that period. T-tests reject the null that the average fallow period in 2001 was the same as in 1985 at the 95\% confidence level and reject the null that it was the same in 2001 as in 1997 at the $99 \%$ confidence level indicating that it increased. Note however that the sample sizes are not the same for all sub-periods.
} 
across villages - in some only males above a certain age were counted, in others all adults were counted, and in others children were included as well. Official population density data is available at the 'department' 12 level which is two units of aggregation above the village (Institut National de la Statistique 2007). Rows 5 and 6 in table 1 report the average population density in 2001 for the departments from which the villages in the survey were sampled and their average rate of growth between 1987 and 2001. Even if population figures were available at the village level, it is doubtful that they would be useful in capturing a sense of 'population pressure' in many of the villages where there is still a forest frontier and village boundaries can be flexible. Thus it would be difficult to interpret an official 'population density' statistic in a context where people have the option of clearing new land that is formally not considered part of the village (i.e., the denominator in population density is not fixed). To address this issue, a population pressure index is constructed for each village based on the average response to the question: 'does your household have as much land as it wants?' The index is calculated as 1 - 'the average proportion of households who believed that there was enough land for their household'. The value of this index is reported in row 8 of table 1. A simple OLS regression of this measure of population pressure at the village level on the department level population density in 2001 indicates that that the department level population density is statistically significant at the $99 \%$ level and the overall fit of the model is good $\left(\mathrm{R}^{2}=.35\right)$, giving some assurance that this measure is indeed reflecting land scarcity. ${ }^{13}$

The degree of market participation is measured by the proportion of the food crop harvest that a household sold (row 9). Farmers in southern Cameroon are almost exclusively net sellers of agricultural goods in contrast to some regions where farmers can be both net buyers and net sellers.

\footnotetext{
${ }^{12}$ Cameroon is divided into seven provinces each of which is divided into departments. Departments are further divided into 'arrondissements' which comprise several villages.

${ }^{13}$ A tobit regression was also run to account for some clustering of the population density index at zero with qualitatively similar results.
} 
Most of the households in the sample are not purely subsistence households, but neither can they be considered to be purely commercial farmers with respect to food production since all of the households in the sample consumed at least part of their own production.

\section{Fallow Choice}

\section{A. Cross-Sectional Data}

\section{i. Estimation Strategies}

As discussed above, the conventional view is that fallow periods in sub-Saharan Africa have been declining due to increases in population density and greater participation in markets. Thus my empirical strategy to test this hypothesis is to examine whether reasonable proxies for these processes are associated with differences in fallow periods in a sample of households from the humid forest zone of Cameroon. The theoretical models described in Section II use agricultural output prices as a proxy for these processes, but this does not allow one to differentiate between changes due to population pressure and those due to market participation. In addition, price differences can also arise from other sources making a more direct approach to measuring these effects preferable. In this study, instead of using prices as a proxy for the two processes, perception and behavior variables are used to try to capture differences in population pressure and market participation among households.

First, the question of how market participation and population pressure affect fallow choice is examined cross-sectionally using the data from the second wave of the panel. While population growth and market penetration are both inherently dynamic processes, it seems logical that they would result in cross-sectional patterns; i.e., if increases in population density and market participation result in lower fallow periods, then areas with higher population densities and a larger extent of market participation should exhibit different fallowing practices. The cross-sectional analysis is done first to take advantage of the richer variable set from the second panel wave. Later, the panel feature of the 
dataset will be exploited to look at changes over time, but with a more restricted set of independent variables.

The cross-sectional reduced form fallow model takes the form:

$$
F=\alpha+\beta \mathrm{X}+\gamma \mathrm{H}+\varepsilon
$$

where $\mathrm{F}$ is a vector consisting of the average fallow period for each household, $\mathrm{X}$ is a vector consisting of measures of population pressure and market participation, $\mathrm{H}$ is a vector of household characteristics, and $\varepsilon$ is a vector of error terms. Since fallow is really an input into production, if households operated in a context of perfect markets, then their choice of inputs would be independent of their household characteristics (Singh et al. 1986). In the context of rural Cameroon, however, markets for land are non-existent and labor markets are far from perfect resulting in the possibility that production and consumption decisions are non-separable. In this case, it is quite possible that household characteristics would affect input choice.

Several econometric specifications of this relationship are tested and results are presented in table 2 below. First, a simple OLS specification (with standard errors corrected for village-level clustering) is estimated as a 'benchmark'. The OLS has two main shortcomings in the context of this study; it ignores censoring issues and suffers from potential endogeneity.

Since all reported fallow lengths above 20 years were converted to 20 years and thus were 'censored' at 20, a tobit regression is estimated next and results are reported in column II of table 2. The definition of fallow for this regression includes an assigned value of 20 for fields cleared from forests (this dependent variable is called 'fall' and corresponds to row 1 in table 1).

There is potential endogeneity at the household level between its fallow length choice and its marketing of a crop. ${ }^{14}$ In order to address this concern, I calculate the village average proportion of

\footnotetext{
${ }^{14}$ This could be due to an omitted variable such as soil quality which when high might result in lower fallow periods and higher output which in turn might result in a larger marketable surplus.
} 
food crops marketed with the household under consideration excluded. Thus this variable is an average of the extent of 'everyone else's' market participation in the village and is highly correlated with the household's marketing behavior, but is purged of possible bias at the household level. It captures the 'market environment' for food crops faced by the household. Column III reports the results from an instrumental variable tobit regression where the above described variable is used as an instrument for the household level proportion of marketed crops and the dependent variable includes fields cleared from forest ('fal1'). Column IV uses the same specification as Column III, but with the dependent variable limited to fields that were cleared from older fallows ('fal2').

Villages that are geographically closer to each other could be affected by similar nonobservables. These could be cultural, institutional, or biophysical (e.g., similar rainfall patterns, soil types, etc.). If these omitted variables vary spatially, then the error term of the regression will be spatially autocorrelated and the estimates will be inefficient. In order to address this issue, I run a spatial error regression. The spatial error model estimates equation (1) from above along with the following equation for the error term ${ }^{15}$ :

$$
\varepsilon=\lambda \mathrm{W} \varepsilon+\mathrm{u}
$$

where $\lambda$ is a spatial autoregressive coefficient, $\mathrm{W}$ is a spatial weights matrix, and $\mathrm{u}$ is a vector of independent, identically distributed errors (Anselin, 1988). The spatial weights matrix, W, describes the spatial relationship among the observations; it defines who is a 'neighbor' for each observation. The spatial configuration of the villages in the study makes the definition of who is a neighbor in the sample somewhat heterogeneous. As can be seen in Figure 1, while the villages in the east are very close to one another, those in the center and south are much more spread out. A 'k-nearest neighbor' spatial weights matrix is used because it ensures that each observation has the same number of

\footnotetext{
${ }^{15}$ The spatial weights matrix and spatial error model were estimated using the spwmatrix and spmlreg Stata modules created by Wilner (2010).
} 
neighbors despite the spatial heterogeneity in the sample. ' $\mathrm{K}$ ' is set equal to five ${ }^{16}$; thus the five closest villages to each village are considered its 'neighbors'. Results from the spatial error regression model are reported in column $\mathrm{V}$ of table 2.

An important shortcoming in the dataset used for this study is the lack of information on soil quality. If fallow lengths are affected by soil characteristics and other biophysical factors which are left out of the regression, there is the possibility of omitted variable bias. The spatial error model corrects for spatial autocorrelation of fallow periods at the village level which could be caused by similar biophysical attributes including soil quality across villages that are close to each other; but this does not address plot level differences at the household level. The best solution to this problem would obviously be to include plot level soil characteristics in the regression, but such data were not collected. The second-best solution is to examine how serious this bias is likely to be and to try to understand how it might affect the regression results. ${ }^{17}$ If the omitted variables are orthogonal to the other regressors, then we do not need to be concerned with bias and can take the existing estimates and t-statistics at face value while keeping in mind that the model is only capturing limited aspects of the phenomenon that we are trying to understand. Average distance to fields is likely to be correlated with soil quality at the household level. It is also plausible that the primary activity of the male or female head of the household could be affected by the soil quality of her/his fields; so that individuals that do not have access to good soils may be more likely to work outside of agriculture. And finally, village natives might have access to better soils than new migrants. In order to see if the inclusion of these variables is an important source of bias for the other coefficients of the model, the tobit instrumental variable regression was re-run without these variables.

\footnotetext{
${ }^{16}$ The number of neighbors used in the matrix is five since there is no theoretical reason to choose a particular number of neighbors and this number seemed to fit the data best.

${ }^{17}$ Another way to address this issue is to find an instrument that is highly correlated with the omitted variable, but uncorrelated with the error term. There was no such instrument in the dataset that met those criteria.
} 
Results are reported in the last column of table 2. The IV tobit model with fallows included from all fields ('fal1') reported in Column III is the preferred model since it corrects for censoring and the potential endogeneity of the marketing variable and uses the largest available sample since it also includes fields cleared from forests. The first two regressions reported can best be considered 'benchmark' models since they do not instrument for the market variable. The last two models are provided as robustness checks.

\section{(insert table 2 here)}

\section{ii. Discussion}

Higher population pressure is associated with statistically significant shorter average fallow periods in all specifications. The negative relationship between population pressure and fallow lengths appears to support one of the claims of the conventional wisdom as outlined in the beginning of this paper.

Another possible interpretation of the significant negative relationship between average fallows and population density is that it might be capturing reverse causality where areas that have rich, fertile soils, have over time attracted more farmers thus acquiring higher population densities. Since the soils are naturally very fertile, they may not require as long a fallow period to regenerate. There are several reasons to doubt this second interpretation. After World War I, France became the colonial power in southern Cameroon. From the 1930s, the French practiced a policy known as 'regroupement' (resettlement), in which existing villages were forcibly moved to roadsides in order to facilitate tax collection, census taking, and labor recruitment (Burnham, 1975). Thus the placement of villages to some extent was exogenous. There is still the possibility that after independence in 1960, villages that were fortuitously located on more fertile soils attracted more in-migration. In this sample of 
households, only $6 \%$ of respondents were not originally from the village where they resided (see table 1, row 16) so a large flow of migration does not appear to have occurred in the recent past.

Proportion marketed was not statistically significant in any of the non-instrumental variable regressions (OLS, tobit, and spatial error regression). There is, however, as described above, potential endogeneity between the household's fallow choice and its marketing of crops. The coefficient on the instrumented market variable increases substantially in all the IV specifications and is negative and statistically significant. The first stage F-statistics reported in table 2 indicate that the instrument is 'strong' and the Hausman test results indicate that own proportion marketed is indeed endogenous. Overall, it seems that there is a statistically significant negative relationship between fallow periods and market participation once endogeneity is taken into account. Thus both higher population pressure and greater commercialization of food crops are associated with lower fallow periods as would be expected if the conventional wisdom linking shifting cultivation and land-degradation were correct.

Higher educational attainment of the head of household is associated with longer fallow periods across all specifications. One possible explanation for this relationship is that both variables are affected by an individual's time rate of preference. Those individuals who are more patient are willing to forego immediate income by investing in their human capital and these same individuals are also more willing to forego immediate profits by investing more in soil fertility. It is also possible that farmers with more education earn higher incomes which allow them to 'invest' more in their soil fertility by leaving their land in fallow for longer periods. ${ }^{18}$

Men whose primary activity is agriculture also tend to leave their land in fallow for longer periods. The dummy for female-headed households is only statistically significant for the noninstrumental variable regressions. This may be because female-headed households comprise a relatively small proportion of the sample (8\%) and are more concentrated in a few villages where

\footnotetext{
${ }^{18}$ I would like to thank an anonymous referee for this point.
} 
average marketing behavior is higher; therefore, the instrument which controls for average marketing behavior, may be weakening the effect of the female-headed variable.

The dummy representing 'village native' is not statistically significant in any of the regressions. Some have argued that newly settled migrants who have less access to land and little knowledge of local ecology use more environmentally destructive practices (Myers, 1992). In this sample, however, migrants do not appear to be using substantially different techniques at least with respect to fallowing periods.

The most important difference from the use of the more restricted fallow definition (reported in column IV in table 2) is that the coefficients on both the population pressure index and on the market participation variable drop substantially. This is likely due to there being fewer fields included with longer fallow periods relative to the sample with forest fields reducing the range of effects. Both coefficients, however, remain statistically significant.

The spatial error results reported in columns V are most comparable to the OLS benchmark because the regression does not use the instrumental variable for proportion marketed nor does it take into account the censoring of the dependent variable. The coefficients should not be taken literally; the results are presented as a robustness check to make sure that the other results are not seriously affected by inefficiency due to omitted variables that are spatially auto-correlated. The likelihood ratio test statistic is significant confirming that the spatial model is different from the null of the classic regression specification. The spatial lag coefficient is statistically significant and positive indicating that there is in fact spatial autocorrelation in the error term. After correcting for spatial correlation, the t-statistics are not substantially different from those in the OLS regression reported in column I indicating that spatial correlation is not substantially reducing efficiency. This is not very surprising since although the spatial lag coefficient is statistically significant, it is relatively small in magnitude. 
And finally, the results in column VI of the specification in which variables that are potentially correlated with soil quality variables are omitted, do not exhibit any dramatic changes in signs or statistical significance. Most importantly, both of the key variables of interest ('population pressure' and 'market environment') remain statistically significant. Thus although soil quality is an important omitted variable, it is unlikely that its omission is resulting in strong bias.

\section{B. Changes in Fallow over Time}

\section{i. Estimation Strategy}

Since the independent variables of interest are either fixed by definition, vary uniformly over the sample (age), or were unavailable from the earlier wave of the panel, it is not possible to use panel regression methods to examine optimal fallow choice. Instead, I examine whether households in villages that experienced greater population pressure and that sold a greater proportion of their output in 2001 had larger reductions in their fallow periods over time. The questionnaire administered in 1998 asked households for their most recent fallow periods, but also asked them to recall their average fallows for 1993 and 1985. Land that had been cleared from forest was not included in the earlier wave so the data used in the analysis for 2001 only includes fallow periods from fields cleared from older fallows as well ('fal2'). A set of three new dependent variables is created by taking the difference between fallow periods in 2001 and each of the three years that are available in the dataset. The regression model takes the form

$$
\Delta F_{01 t}=\alpha+\beta \mathrm{X}+\gamma \mathrm{H}+\varepsilon
$$

where $\Delta F_{01 t}$ is the difference in the household's average fallow period between year 2001 and $t$ $=1985,1993$, and 1997, $\mathrm{X}$ is a vector consisting of measures of population pressure and extent of market participation, $\mathrm{H}$ is a vector of household characteristics, and $\varepsilon$ is a vector of error 
terms. The only data for the independent variables that are used from the beginning of each period are the ages of the household heads. All other independent variables used are timeinvariant. An instrumental variable strategy is used as in the cross-sectional regressions above with the 'market environment' variable serving as the instrument for proportion marketed.

The panel is unbalanced because not all the households surveyed in 2001 farmed in all four years (this is especially true for the younger household heads) and some respondents did not recall their fallow periods from the earlier periods. There are 322 observations for the shortest time period, but only 161 for the longest one. By using the data for all sub-periods (as opposed to just the longest), we can take advantage of the greater number of observations. It also makes it possible to investigate whether there were differences in the relationships for any of the subperiods given the non-linear pattern in average fallow periods across the sub-periods reported in the summary statistics. In order to be sure that the results are not affected by sample selection bias, the same regressions are run for both the unbalanced and balanced panel. ${ }^{19}$ Results are reported in table 3 .

(insert table 3 here)

\section{ii. Discussion}

There is a statistically significant negative relationship between fallow length and the population pressure index for all periods and for both samples. Thus households that were in villages with greater land scarcity in 2001 reduced their fallow periods more (or increased their fallow periods less) than households in villages that were not affected by population pressure.

While there was evidence for a cross-sectional relationship between those who marketed more of their output and lower fallow periods in the instrumental variable regressions, there was no reduction in fallow periods over time among the households that marketed more of their output in

\footnotetext{
${ }^{19}$ The balanced panel only has 139 observations since those were the households who farmed all four years.
} 
2001. This may be because the market environment has been relatively stable over the time period so that households that marketed more of their output in 2001 also did so in the earlier periods. There has been little infrastructure development in the rural areas of southern Cameroon over the last two decades so that would not be surprising, but since we do not have data on marketing for the earlier periods it is not possible to verify whether or not this is the case.

Two main differences stand out between the results for the unbalanced and balanced samples. First, the magnitude of the population coefficient declines for all time periods (but remains statistically significant). Second, the age variables are statistically significant (and of opposing signs for men and women) for almost all of the unbalanced panel results but are not statistically significant for the balanced panel dataset. For the unbalanced sample, the results indicate that older male heads of households appear to have reduced their fallow periods more than average across the different time periods, while older females tended to increase their fallow periods over time. Since the clearing of

fields tends to be male work and weeding and harvesting tend to be women's work, these results could reflect an increase in household bargaining power in cultures where age is respected. The labor for clearing fields tends to increase with the age of the fallows so a man would prefer to clear younger fallows; and weeding labor decreases with the age of fallows (Dvorak, 1992) so a woman would prefer to use fields with older fallows. The balanced sample is on average older than the unbalanced sample (because the younger heads of households would have been the least likely to have cultivated land in 1985) so the lower variability in ages in this sample may explain why the age differences are no longer statistically significant in the balanced sample.

\section{Fallows and Declining Soil Fertility}

\section{A. Estimation Strategy}


It is important to emphasize that while lower fallow periods might be a necessary condition for deforestation as described by the conventional narrative, it is not a sufficient condition. In order for lower fallow lengths to result in degradation-induced deforestation, they would have to be low enough to reduce soil fertility thereby affecting yields. If fallow periods are falling below the biological threshold necessary for adequate soil fertility generation either to sustain yields or to support forest growth, they should be a constraining input for production. In other words, if soils are becoming depleted of fertility due to low fallow lengths, then this should manifest in less output. To try to test for this, several regressions are run to estimate the marginal impact of fallow length on the value of output of food crops using the 2001 data (the earlier wave of the survey did not include questions on output).

In order to take into account potential technical inefficiencies in production and to estimate the 'best-practice' impact of fallow on production, a stochastic frontier approach is adopted. The idea of using stochastic frontier models to take into account production inefficiency was first proposed by Aigner et al. (1977) and Meeusen and van der Broek (1977). This approach is used to deal with the fact that the error term in econometric estimates of a production function, will in general be composed of two distinct effects: a random noise component and a technical inefficiency component. Stochastic frontier models attempt to separate out the two effects by modeling the technical inefficiency component of the error term as a non-negative random variable which is assumed to be independent of the statistical noise component of the error.

Two types of stochastic frontier production function models are estimated. Model 1 estimates a 'traditional' stochastic frontier model (Battese and Coelli, 1992) for both a translog and CobbDouglas production function and for both definitions of fallow. The translog model to be estimated takes the following form: 
$\ln Y=\beta_{0}+\sum_{j=1}^{3} \beta_{j}\left(\ln X_{j}\right)+\sum_{j=1}^{3} \sum_{k=1}^{3} \beta_{j k}\left(\ln X_{j}\right)\left(\ln X_{k}\right)+\sum_{m=1}^{48} \lambda_{m} V i l l_{m}+V-U$

where Y represents the value of output; the $\mathrm{X}$ inputs are land, labor, and fallow period; 48 village dummies are included to control for unobserved heterogeneity across villages; $\mathrm{V}$ is a vector composed of the random noise component of the error assumed to be iid, $\mathrm{N}\left(0, \sigma_{\mathrm{v}}{ }^{2}\right)$; and $\mathrm{U}$ is a vector of nonnegative random variables that account for technical inefficiency in production and are assumed to be iid and independent of $\mathrm{V}$. The technical inefficiency component of the error is assumed to follow a truncated half-normal distribution $\mathrm{N}\left(\mu, \sigma_{\mathrm{u}}{ }^{2}\right)$. The Cobb Douglas specification is just a special case of the model above, with the input interaction effects assumed to be zero.

Model 2 is a non-neutral stochastic frontier model proposed by Huang and Liu (1994) where the technical inefficiency component is modeled as a function of the characteristics of the farmers and of interactions between these characteristics and the production inputs. Thus it allows one to test whether technical efficiency is affected by farmers' characteristics and whether these effects vary with different levels of input use. Model 2 consists of an estimation of equation (4) along with the following:

$U=\delta_{o}+\sum_{j=1}^{6} \delta_{j} Z_{j}+\sum_{j=1}^{6} \sum_{k=1}^{3} \delta_{j k} Z_{j} X_{k}+W$

where the $\mathrm{Z}$ variables include: age of the male of head of household, age of the oldest wife or of the female head of household, years of education of the male head of the household (or female if it is a female-headed household), a dummy for whether the head of household is a man or woman, a dummy for whether agriculture is the primary activity of the male, and a dummy for whether agriculture is the primary activity of the female; the $\mathrm{X}$ inputs are those described above for equation 4 , and $\mathrm{W}$ is a vector of random normally distributed error terms. 
Both models are estimated for the two types of production functions - translog and CobbDouglas as well as for the two definitions of fallow periods ('fal1' and 'fal2'). OLS regression results for both production functions and both definitions of fallow are presented as a 'benchmark' and an indication of actual (as opposed to 'efficient') practice in Table 4A. Results from the estimation of the two types of stochastic frontier models are reported in table $4 \mathrm{~B}^{20}$ and the results for the estimation of the determinants of technical inefficiency for Model 2 are reported in table 4C. (insert tables 4A, 4B, and 4C here)

\section{B. Discussion}

The key finding of the OLS regressions is that the fallow period is not statistically significant in any of the specifications. Labor is significant in the OLS Cobb-Douglas regressions, but not in the translog regressions (although its squared term is statistically significant). Likelihood ratio tests indicate that the translog specification is the more appropriate model for the OLS regressions.

The stochastic frontier results indicate that there is indeed some degree of technical inefficiency in the sample. For all specifications of Model 1, likelihood ratio tests reject the null hypothesis that there is no inefficiency in the sample. The average degree of technical efficiency ranges from $63 \%$ to $96 \%$ depending on the model specification. Likelihood ratio tests reject the null hypothesis that the Cobb-Douglas is an adequate representation of the production technology for both definitions of fallow in Model 1; thus for Model 1, the translog specifications are more appropriate. For Model 2, however, a likelihood ratio test fails to reject that the Cobb-Douglas functional form is appropriate when all fields including those cleared from forest are included ('fall'). When the data are restricted to those fields cleared from previous fallows ('fal2'), the likelihood function of the translog

\footnotetext{
${ }^{20}$ The estimation of the likelihood function for Model 2 with 'fal2' failed to converge so the results of this estimation are not found in the table.
} 
specification fails to converge. Thus the results for Model 2 are discussed with reference to the Cobb Douglas specification for both definitions of fallow.

Both land and labor are statistically significant in all but one of the 'preferred' stochastic frontier models (labor is not statistically significant in TL 'fal2', but its squared term is). The fallow input is not statistically significant in any of the specifications. The only household characteristic that seems to have a direct effect on efficiency is the primary activity of the male head of household. When all fields including those cleared from forest are considered, the Cobb-Douglas specification indicates that having a male head of household whose primary activity is agriculture reduces technical inefficiency. When only fields cleared from previous fallows are analyzed, however, this variable is no longer statistically significant. Several of the interaction effects between inputs and household characteristics were statistically significant for both Cobb-Douglas specifications indicating that the technology is non-neutral.

The major finding of the production function regressions of relevance for this study is that the fallow period is not statistically significant in any of the specifications. The coefficient on fallow for the stochastic non-neutral production frontier specification can be interpreted as the elasticity of the ‘best practice production' with respect to fallow (Battese and Broca, 1997). Thus fallow is not a binding constraint on production either in actual practice (as indicated by the OLS regression results) nor on the production frontier.

These results imply that for this sample of households in Cameroon, fallow lengths are not low enough to be affecting yields. If shifting cultivation were in fact causing soil degradation due to declining fallow lengths as the conventional narrative claims, one would expect to see a strong response of yields to fallow periods. The evidence presented here, however, indicates that this is not the case. While households may respond to increasing population pressure by reducing fallow 
periods, they are not reducing fallow periods by enough on average to reach a biological threshold at which soil recovery is at risk. There appears to be some room for fallow adjustment in this region before the biological threshold for soil degradation sets in.

\section{Conclusion}

The commonly-cited narrative for degradation-induced deforestation caused by shifting cultivators in tropical Africa involves several connected claims. It posits that increases in population and greater participation in markets result in a reduction of fallow periods; that these lower fallow periods result in a decline of soil fertility; that the decline in soil fertility results in lower yields pushing farmers to clear more forests; and that the soils on the abandoned plots are so degraded that forest vegetation can no longer regenerate. This paper explores the evidence behind some of these claims in southern Cameroon.

Results from the cross-sectional analysis show that there is indeed evidence that population pressure and market participation are associated with lower fallow periods in this region. There is also evidence that households in villages that experienced greater population pressure reduced their fallow

periods between 1985 and 2001 by a greater amount than households for whom land scarcity was not a concern. No evidence is found, however, that fallow lengths are currently low enough to be having a detrimental effect on output as would be expected if soil fertility were being dangerously depleted. Since soil degradation is a necessary condition for the 'land-degradation deforestation' hypothesis to hold, the results do not support the contention that shifting cultivators are causing degradation-induced deforestation in this region of southern Cameroon. 


\section{References}

Ahuja, V. 1998. "Land Degradation, Agricultural Productivity and Common Property: Evidence from Côte d'Ivoire.” Environment and Development Economics 3: 7-34.

Aigner, D.J., C.A.K. Lovell, and P. Schmidt. 1977. "Formulation and estimation of stochastic frontier production functions." Journal of Econometrics 6: 21--37.

Albers, H.J. and M. Goldbach. 2000. "Irreversible Ecosystem Change, Species Competition, and Shifting Cultivation.” Resource and Energy Economics 22(3): 261-280.

Amelung, T. and M. Diehl. 1992. Deforestation of tropical rain forests: economic causes and impact on development, Tübingen : J.C.B. Mohr.

Angelsen, A. and D. Kaimowitz. 2001. "Introduction: the Role of Agricultural Technologies in Tropical Deforestation." in Angelsen, A. and D. Kaimowitz, eds. Agricultural Technologies and Tropical Deforestation. Wallingford, UK: CAB International.

Anselin. L. 1988. Spatial Econometrics, Methods and Models, Boston: Kluwer Academic. Aweto, A, O. \& A.O. Iyanda. 2003. "Effects of Newbouldia Laevis on Soil Subjected to Shifting Cultivation in the Ibadan Area, Southwestern Nigeria." Land Degradation \& Development.14: 51-56.

Banful, B., S. Hauser, K. Ofori, and F. Kumaga. 2007. "Weed biomass dynamics in planted fallow systems in the humid forest zone of southern Cameroon." Agroforestry Systems. 71:49-55.

Barrett. S. 1991. "Optimal soil conservation and the reform of agricultural pricing policies" Journal of Development Economics 36: 167-187.

Battese, G.E., and S.S. Broca. 1997. "Functional Forms of Stochastic Frontier Production Functions and Models for Technical Inefficiency Effects: A Comparative Study for Wheat Farmers in Pakistan." Journal of Productivity Analysis 8: 395-414.

Battese, G. E. and T. J. Coelli. 1992. "Frontier Production Function, technical efficiency and panel data: with application to Paddy Farmers in India," Journal of Productivity Analysis 3: 153-169.

Boserup, Ester. 1965. The Conditions of Agricultural Growth. Chicago: Aldine Publishing Company.

Brady, N. 1996. Alternative to Slash and Burn: A Global Imperative." Agriculture, Ecosystems, and Environment 58:3-11.

Bulte, E. and D. van Soest. 1999. "A note on soil depth, failing markets, and agricultural pricing." Journal of Development Economics 58:245-254.

Burnham, P. 1975. “' 'Regroupement' and Mobile Societies; Two Cameroon Cases.” The Journal of African History, 16(4):577-594. 
Degrande, A. 2001. "Farmer assessment and economic evaluation of shrub fallows in the Humid Lowlands of Cameroon." Agroforestry Systems. 53: 11-19.

Dvorak, K. 1992. "Resource Management by West African Farmers and the Economics of Shifting Cultivation." American Journal of Agricultural Economics 74(3): 809-15.

FAO. 2001. “Global Forest Resources Assessment 2000 Summary Report” FAO: Rome.

Franzel, S. 1999. "Socioeconomic factors affecting the adoption potential of improved tree fallows in Africa." Agroforestry Systems 47: 305-321.

Hassan, R., R. Scholes, and N. Ash. 2005. Ecosystems and Human Well-being. Washington, D.C.:Island Press.

Huang, C.J. and J.-T. Liu. 1994. "Estimation of a non-neutral stochastic frontier production function"Journal of Productivity Analysis 5: 171 - 180.

Ickowitz, A. 2006. "Shifting Cultivation and Deforestation in Tropical Africa: Critical Reflections." Development and Change 37: 599-626.

Institut National de la Statistique. 2007. Annuaire Statistique du Cameroun 2006:

http://www.statistics-cameroon.org/.

Jeanty, P.W.2010. spmlreg: Stata module to estimate the spatial lag, the spatial error, the spatial durbin, and the general spatial models. Available from http://ideas.repec.org/c/boc/bocode/s457135.html

Jeanty, P.W. 2010. spwmatrix: Stata module to create, import, and export spatial weights. Available from http://ideas.repec.org/c/boc/bocode/s457111.html.

Jepma, C.J. 1995. Tropical Deforestation: A Socio-Economic Approach. London: Earthscan Publications.

Juo, A. and A. Manu. 1996. "Chemical Dynamics in Slash-and-Burn Agriculture." Agriculture,Ecosystems and Environment 58: 49-60.

Kleinman, P.J., D. Pimentel, and R.B. Bryant. 1995. "The Ecological Sustainability of Slash and Burn Agriculture." Agriculture, Ecosystems, and Environment 52: 235-249.

Kotto-Same, J., P. Woomer, M. Appolinaire, Z. Louis. 1997. "Carbon dynamics in slash-andburn agriculture and land use alternatives of the humid forest zone in Cameroon." Agriculture, Ecosystems and Environment 65: 245-256.

Krautkraemer, J.A.1994. "Population growth, soil fertility, and agricultural intensification." Journal of Development Economics 44: 403-428. 
Lanly, J. P. 1982. Tropical Forest Resources, Rome: FAO.

Meeusen, W., and J. van den Broeck. 1977. "Efficiency Estimation from Cobb-Douglas Production Function with Composed Error." International Economic Review 8: 435-444.

Mertens, B. and E. Lambin. 2000. "Land Cover Trajectories in Southern Cameroon." Annals of the Association of American Geographers. 90(3): 467-94.

Mertens, B., W. Sunderlin, O. Ndoye, and E. Lambin. 2000. "Impact of Macroeconomic Change on Deforestation in South Cameroon.” World Development 28(6): 983-999.

Mertz, O. 2002. "The Relationship between Length of the Fallow and Crop Yields in Shifting Cultivation: A Rethinking." Agroforestry Systems 55:149-59.

Myers, N. 1992. “Tropical Forests: The Policy Challenge.” The Environmentalist 12: 15-27.

Nye, P. and D. Greenland. 1996. The Soil Under Shifting Cultivation. Farnham Royal, UK: Commonwealth Agricultural Bureaux.

Padoch, C., K. Coffey, O. Mertz, S. Leisz, J. Fox, and R. Wadley. 2007. "The Demise of Swidden in Southeast Asia? Local Realities and Regional Ambiguities." Danish Journal of Geography 107(1): 29-41.

Pascual, U. and E. Barbier. 2006. "Deprived land-use intensification in shifting cultivation: the population pressure hypothesis revisited.” Agricultural Economics 34: 155-165.

Ruthenberg, H. 1980. Farming Systems in the Tropics. New York: Oxford University Press.

Singh, I., L. Squire, and J. Strauss.1986. Agricultural Household Models. Baltimore: Johns Hopkins University Press.

Sivakumar, M.V.K. and C. Valentin. "Agroecological zones and crop production potential.” Phil. Trans. R. Soc. 1997.

Sunderlin, W.D., O. Ndoye, H. Bikié, N. Laporte, B. Mertens, and J. Pokam. 2000. "Economic crisis, small-scale agriculture, and forest change in southern Cameroon." Environmental Conservation 27 (3): 284-290.

Sunderlin, W.D. and J. Pokam. 2002. "Economic Crisis and Forest Cover Change in Cameroon: The Roles of Migration, Crop Diversification, and Gender Division of Labor." Economic Development and Cultural Change. 50(3): 581-606.

Szott, L.T., C.A. Palm, and R.J. Buresh. 1999. "Ecosystem fertility and fallow function in the humid and subhumid tropics." Agroforestry Systems. 47: 163-196. 
Talbott, K. 1993. Central Africa's forests: the second greatest forest system on earth. Washington, D.C.: World Resources Institute.

Thiele, R. and M. Wiebult. 1994. "Policies to Reduce Tropical Deforestation and Degradation: A Computable General Equilibrium Analysis for Cameroon.” Quarterly Journal of International Agriculture 33: 162- 178.

Thrupp, L. A., S. Hecht and J. Browder. 1997. The Diversity and Dynamics of Shifting Cultivation: Myths, Realities, and Policy Implications. Washington, DC: World Resources Institute.

Tinker, P.B., J.S. Ingram, and S. Struwe. 1996. "Effects of Slash and Burn Agriculture on Climate Change." Agriculture, Ecosystems, and Environment 58:3-11. 
Figure 1 - Map of Villages Surveyed in Southern Cameroon

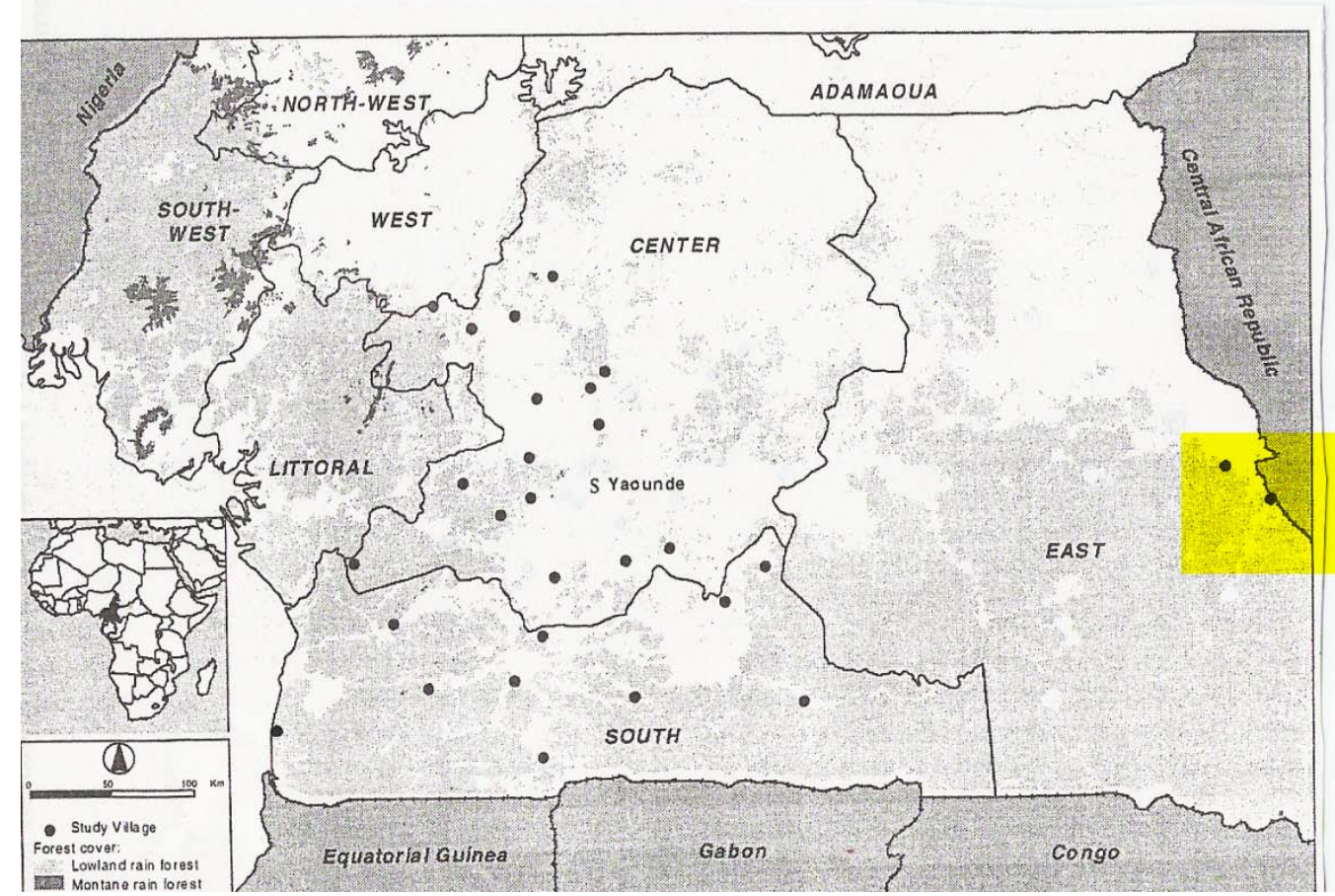

Map adapted from Sunderlin et al., 2000 
Table 1: Summary Statistics from Cameroonian Survey (means with standard deviations in parentheses)

\begin{tabular}{|c|c|c|c|c|}
\hline 1. Fallow length with forest field $=20$ ('fall') & $\begin{array}{l}\text { Wave I } \\
(1985)\end{array}$ & $\begin{array}{l}\text { Wave I } \\
\text { (1993) }\end{array}$ & $\begin{array}{l}\text { Wave I } \\
(1997)\end{array}$ & $\begin{array}{l}\text { Wave II } \\
(2001) \\
7.74 \\
(5.45)\end{array}$ \\
\hline 2. Fallow length of food crops in yrs. ('fal2') & $\begin{array}{l}4.65 \\
(2.28)\end{array}$ & $\begin{array}{l}4.52 \\
(2.53)\end{array}$ & $\begin{array}{l}4.90 \\
(3.16)\end{array}$ & $\begin{array}{l}5.82 \\
(3.86)\end{array}$ \\
\hline 3. Number of food fields per household & & & & $3.2(1.6)$ \\
\hline 4. Distance to fields in $\mathrm{km}$ & & & & $1.8(1.7)$ \\
\hline 5. Population density at department level & & & & $\begin{array}{l}19.5 \\
(16.6)\end{array}$ \\
\hline $\begin{array}{l}\text { 6. Population growth rate at department level } \\
(1987-2001)\end{array}$ & & & & $.38(.16)$ \\
\hline 7. Believe that there is enough land for her/his hh & & & & $.90(.29)$ \\
\hline 8. Average Population Pressure Index & & & & $.09(.16)$ \\
\hline 9. Proportion of food crops marketed per hh & & & & $.41(.30)$ \\
\hline 10. Market Environment Index & & & & $.42(.23)$ \\
\hline 11. Age of male head of hh & & & & $48.6(15.11)$ \\
\hline 12. Age of wife or female head of hh & & & & $42.8(14.0)$ \\
\hline 13. Yrs of education of head of hh & & & & $5.7(3.1)$ \\
\hline 14. Primary activity male head of hh is agr. & & & & $.86(.34)$ \\
\hline $\begin{array}{l}\text { 15. Primary activity of wife of } \\
\text { head of hh is agr. }\end{array}$ & & & & $.83(.38)$ \\
\hline 16. Village native & & & & $.94(.24)$ \\
\hline 17. Harvest value in thousands of CFA & & & & $512(648)$ \\
\hline 18. Average change in fallow $1985-2001$ & & & & $\begin{array}{l}3.06 \\
(6.04)\end{array}$ \\
\hline 19.Average change in fallow $1993-2001$ & & & & $\begin{array}{l}3.03 \\
(5.94)\end{array}$ \\
\hline 20. Average change in fallow $1997-2001$ & & & & $\begin{array}{l}2.74 \\
(6.13)\end{array}$ \\
\hline 21. Labor (number of working days per year) & & & & $722(428)$ \\
\hline 22. Land (size of food crop fields in square meters) & & & & $\begin{array}{l}24,351 \\
(68,713)\end{array}$ \\
\hline 23. \# of household members & & & & $7.05(4.46)$ \\
\hline 24. East Province & & & & $.46(.50)$ \\
\hline 25. Center Province & & & & $.35(.48)$ \\
\hline 26. South Province & & & & $.19(.39)$ \\
\hline Number of observations & 161 & 250 & 322 & 365 \\
\hline
\end{tabular}


Table 2: Regression Results for Cross-Sectional Fallow Model (t-statistics in parentheses)

Dep. Variable:

avg fallow period

Key Variables of Interest

Population Pressure Index

Proportion Marketed

Instrumented proportion

marketed (instrument:

market environment)

Household Characteristics

Yrs of education of head hh

Avg. distance to fields in $\mathrm{km}$

Age of male head of hh

Age of female $h h^{\mathrm{c}}$

Primary activity of male

( $1=$ agriculture $)$

Prim. activity of female

( $1=$ agriculture $)$

Gender of head of hh

$(1=$ female $)$

Village native

Province Dummies

South Province

Center Province

Spatial lag coefficient

constant

$N$

$R^{2}$

$F$-stat first stage $(\mathrm{Pr})$

Wald $\chi^{2}$

$L R \chi^{2} \mathrm{~d}$

Hausman test ${ }^{\mathrm{e}}$

\begin{tabular}{|c|c|c|c|c|c|}
\hline I & II & III & IV & $\mathrm{V}$ & VI \\
\hline $\begin{array}{l}\text { OLS }^{\mathbf{a}} \\
\text { (fal1) }\end{array}$ & $\begin{array}{l}\text { Tobit } \\
\text { (fal1) }\end{array}$ & $\begin{array}{l}\text { IVTobit }^{\mathrm{a}} \\
\text { (fal1) }\end{array}$ & $\begin{array}{l}\text { IVTobit }^{\mathrm{a}} \\
\text { (fal2) }\end{array}$ & $\begin{array}{l}\text { Spatial } \\
\text { error } \\
\text { model }^{b} \\
\text { (fal1) }\end{array}$ & $\begin{array}{l}\text { IVTobit w/o } \\
\text { potentially } \\
\text { endog.var.s } \\
\text { (fal1) }\end{array}$ \\
\hline
\end{tabular}

$\begin{array}{llllll}-8.31 * * * & -9.11 * * * & -4.06 * * & -3.10 * * * & -8.42 * * * & -4.87 * * * \\ (-4.19) & (-4.18) & (-2.10) & (-2.65) & (-4.20) & (-2.96) \\ -1.29 & -1.40 & & & -1.15 & \\ (-1.53) & (-1.47) & & & (-1.01) & \\ & & -4.72 * * * & -2.51 * & & -4.12 * * \\ & & (-3.02) & (-1.78) & & (-2.09)\end{array}$

$\begin{array}{llllll}0.23 * * & 0.25 * & 0.19 * * & 0.17 * * * & 0.21 * & 0.18 * * \\ (2.04) & (1.94) & (2.46) & (2.73) & (1.84) & (2.33) \\ 0.32 & 0.40 & -0.05 & -0.06 & 0.33 * * & \\ (1.36) & (1.39) & (-0.36) & (-0.50) & (1.99) & \\ -0.04 & -0.05 & -0.005 & -0.02 & -0.05 & -0.003 \\ (-1.15) & (-1.23) & (-0.16) & (-1.12) & (-1.42) & (-0.11) \\ 0.04 & 0.05 & 0.01 & 0.04 * * & 0.04 & 0.01 \\ (1.22) & (1.25) & (0.59) & (2.13) & (1.21) & (0.58) \\ 1.23 * * & 1.31 * * & 0.78 * * & 0.34 & 1.27 * & \\ (2.44) & (2.38) & (2.27) & (0.91) & (1.63) & \\ 1.09 & 1.13 & 0.83 & 0.66 & 1.16 & \\ (1.36) & (1.30) & (1.23) & (1.15) & (1.49) & \\ 3.21 * * & 3.64 * * * & 1.09 & 1.03 & 3.06 * * * & 0.57 \\ (2.63) & (2.67) & (1.36) & (1.47) & (2.56) & (0.74) \\ 0.15 & -0.29 & 0.16 & -0.22 & 0.09 & \\ (0.16) & (-0.25) & (0.27) & (-0.45) & (0.08) & \end{array}$

$\begin{array}{llllll}-1.58 & -1.79 & -1.71 & 0.07 & -1.39 & -1.94 *\end{array}$

$\begin{array}{llllll}(-1.46) & (-1.51) & (-1.58) & (0.09) & (-1.28) & (-1.83)\end{array}$

$\begin{array}{llllll}0.25 & 0.31 & -1.01 & 0.67 & 0.44 & 0.95\end{array}$

$\begin{array}{lllll}(0.20) & (0.22) & (-0.99) & (0.94) & (0.50)\end{array}$

\begin{tabular}{|c|c|c|c|c|c|}
\hline & & & & $\begin{array}{l}0.03 * * \\
(2.03)\end{array}$ & \\
\hline 5.66 & 5.92 & 6.16 & 4.45 & 4.93 & 7.67 \\
\hline (3.14) & $(3.02)$ & $(3.41)$ & $(3.04)$ & $(2.49)$ & $(4.85)$ \\
\hline 365 & 365 & 365 & 337 & 365 & 365 \\
\hline .11 & & & & .11 & \\
\hline & & 65.80 & 66.74 & & 108.59 \\
\hline & & $(0.00)$ & $(0.00)$ & & $(0.00)$ \\
\hline & & 44.41 & 41.58 & & 22.32 \\
\hline & & $(0.00)$ & $(0.00)$ & & $(0.00)$ \\
\hline & 41.11 & & & & \\
\hline & & 41.15 & 56.45 & & 21.58 \\
\hline & & $(0.00)$ & $(0.00)$ & & $(0.02)$ \\
\hline & & & & 3.96 & \\
\hline
\end{tabular}




\footnotetext{
*significant at $90 \%$ confidence level; $* *$ sig. at $95 \%$ confidence level; $* * *$ sig. at $99 \%$ confidence level

a standard errors corrected for clustering

${ }^{\mathrm{b}} \mathrm{z}$-values in parentheses

${ }^{\mathrm{c}}$ When a household was polygamous, the age of the oldest wife was used. Also, for households with a single male, the average age of the female head of household for the province sample was used as an imputed value so as not to lose the observation.

${ }^{\mathrm{d}}$ The estimates reported in the table were calculated with standard errors clustered at village level, but since the LR test cannot be done with clustered standard errors, it was performed on a model without clustered standard errors.

${ }^{\mathrm{e}}$ All estimates reported were calculated with standard errors clustered at village level, but since the Hausman test cannot be used with clustering, the test was performed using results from regressions without clustered standard errors.
} 
Table 3: IV Regression Results for Changes in Fallow Over Time (t-statistics in parentheses; standard errors corrected for clustering)

\begin{tabular}{|c|c|c|c|c|c|c|}
\hline $\begin{array}{l}\text { Dep. Variable: change in } \\
\text { avg fallow period } \\
\text { between } 2001 \text { and period t }\end{array}$ & $\begin{array}{l}\text { Full } \\
\text { Sample }\end{array}$ & $\begin{array}{l}\text { Full } \\
\text { Sample }\end{array}$ & $\begin{array}{l}\text { Full } \\
\text { Sample }\end{array}$ & $\begin{array}{l}\text { Balanced } \\
\text { Sample }\end{array}$ & $\begin{array}{l}\text { Balanced } \\
\text { Sample }\end{array}$ & $\begin{array}{l}\text { Balanced } \\
\text { Sample }\end{array}$ \\
\hline & $\mathrm{t}=1985$ & $\mathrm{t}=1993$ & $\mathrm{t}=1997$ & $\mathrm{t}=1985$ & $\mathrm{t}=1993$ & $\mathrm{t}=1997$ \\
\hline \multicolumn{7}{|l|}{ Key Variables of Interest } \\
\hline Population Pressure Index & $\begin{array}{l}-8.58 * * * \\
(-3.46)\end{array}$ & $\begin{array}{l}-7.30 * * * \\
(-3.36)\end{array}$ & $\begin{array}{l}-7.75 * * * \\
(-3.52)\end{array}$ & $\begin{array}{l}-7.40 * * * \\
(-3.06)\end{array}$ & $\begin{array}{l}-4.57 * * \\
(-1.97)\end{array}$ & $\begin{array}{l}-4.66^{*} \\
(-1.73)\end{array}$ \\
\hline Instrumented proportion & -0.55 & -0.63 & 0.68 & -2.57 & -2.01 & -1.18 \\
\hline $\begin{array}{l}\text { marketed (instrument: } \\
\text { market environment) }\end{array}$ & $(-0.15)$ & $(-0.18)$ & $(0.23)$ & $(-0.91)$ & $(-0.80)$ & $(-0.45)$ \\
\hline \multicolumn{7}{|l|}{ Household Characteristics } \\
\hline $\begin{array}{l}\text { Years of education of } \\
\text { head of household }\end{array}$ & $\begin{array}{l}-0.07 \\
(-0.45)\end{array}$ & $\begin{array}{l}-0.08 \\
(-0.61)\end{array}$ & $\begin{array}{l}-0.14 \\
(-0.98)\end{array}$ & $\begin{array}{l}0.007 \\
(0.07)\end{array}$ & $\begin{array}{l}0.03 \\
(0.30)\end{array}$ & $\begin{array}{l}-0.01 \\
(-0.14)\end{array}$ \\
\hline $\begin{array}{l}\text { Age of male head } \\
\text { of household }\end{array}$ & $\begin{array}{l}-.08 \\
(-1.66)\end{array}$ & $\begin{array}{l}-0.14 * * * \\
(-3.52)\end{array}$ & $\begin{array}{l}-0.09 * * \\
(-2.37)\end{array}$ & $\begin{array}{l}-.03 \\
(-0.88)\end{array}$ & $\begin{array}{l}-0.05 \\
(-1.46)\end{array}$ & $\begin{array}{l}-0.03 \\
(-0.74)\end{array}$ \\
\hline Age of female & $\begin{array}{l}0.09 * * \\
(2.39)\end{array}$ & $\begin{array}{l}0.13 * * * \\
(3.96)\end{array}$ & $\begin{array}{l}0.07 * \\
(1.78)\end{array}$ & $\begin{array}{l}0.02 \\
(0.72)\end{array}$ & $\begin{array}{l}0.05 \\
(1.65)\end{array}$ & $\begin{array}{l}0.04 \\
(1.18)\end{array}$ \\
\hline Village native & $\begin{array}{l}0.67 \\
(0.47)\end{array}$ & $\begin{array}{l}-0.23 \\
(-0.18)\end{array}$ & $\begin{array}{l}-1.18 \\
(-0.90)\end{array}$ & $\begin{array}{l}0.66 \\
(0.87)\end{array}$ & $\begin{array}{l}1.38 \\
(1.63)\end{array}$ & $\begin{array}{l}0.75 \\
(0.89)\end{array}$ \\
\hline \multicolumn{7}{|l|}{ Province Dummies } \\
\hline South Province & $\begin{array}{l}-4.25^{* *} \\
(-2.48)\end{array}$ & $\begin{array}{l}-3.95 * * * \\
(-2.67)\end{array}$ & $\begin{array}{l}-1.85 \\
(-1.38)\end{array}$ & $\begin{array}{l}-3.65^{* *} \\
(-2.38)\end{array}$ & $\begin{array}{l}-3.20 * * \\
(-2.39)\end{array}$ & $\begin{array}{l}-2.18 \\
(-1.54)\end{array}$ \\
\hline Center Province & $\begin{array}{l}-1.71 \\
(-1.15)\end{array}$ & $\begin{array}{l}-0.15 \\
(-0.11)\end{array}$ & $\begin{array}{l}0.26 \\
(0.18)\end{array}$ & $\begin{array}{l}-1.35 \\
(-1.31)\end{array}$ & $\begin{array}{l}-0.74 \\
(-0.80)\end{array}$ & $\begin{array}{l}-0.36 \\
(-0.38)\end{array}$ \\
\hline constant & $\begin{array}{l}5.10 \\
(1.71)\end{array}$ & $\begin{array}{l}6.88 \\
(2.31)\end{array}$ & $\begin{array}{l}6.95 \\
(2.23)\end{array}$ & $\begin{array}{l}4.32 \\
(1.36)\end{array}$ & $\begin{array}{l}2.96 \\
(1.07)\end{array}$ & $\begin{array}{l}2.56 \\
(0.86)\end{array}$ \\
\hline F-stat First-Stage & $\begin{array}{l}16.31 \\
(0.00)\end{array}$ & $\begin{array}{l}21.38 \\
(0.00)\end{array}$ & $\begin{array}{l}31.68 \\
(0.00)\end{array}$ & $\begin{array}{l}15.60 \\
(0.00)\end{array}$ & $\begin{array}{l}15.60 \\
(0.00)\end{array}$ & $\begin{array}{l}15.60 \\
(0.00)\end{array}$ \\
\hline$N$ & 161 & 250 & 322 & 139 & 139 & 139 \\
\hline$R^{2}$ & .13 & .15 & .10 & .07 & .05 & .03 \\
\hline
\end{tabular}


Table 4A: OLS Production Function Regression Results (t-statistics in parentheses; standard errors corrected for clustering at village level; village dummies included in regressions, but not reported)

\begin{tabular}{|c|c|c|c|c|}
\hline \multicolumn{5}{|l|}{$\begin{array}{l}\text { Dependent Variable: } \\
\text { log harvest value }\end{array}$} \\
\hline & TL ' fal1' & CD 'fal1' & TL 'fal2' & CD 'fal2' \\
\hline In land & $\begin{array}{l}1.20^{* *} \\
(2.56)\end{array}$ & $\begin{array}{l}0.21 * * * \\
(3.92)\end{array}$ & $\begin{array}{l}1.15^{* * * *} \\
(2.70)\end{array}$ & $\begin{array}{l}0.18 * * * \\
(3.35)\end{array}$ \\
\hline In labor & $\begin{array}{l}0.82 \\
(1.35)\end{array}$ & $\begin{array}{l}0.64 * * * \\
(10.67)\end{array}$ & $\begin{array}{l}0.78 \\
(1.06)\end{array}$ & $\begin{array}{l}0.62 * * * \\
(9.25)\end{array}$ \\
\hline ln fallow & $\begin{array}{l}-0.13 \\
(-0.27)\end{array}$ & $\begin{array}{l}0.008 \\
(0.14)\end{array}$ & $\begin{array}{l}0.21 \\
(0.23)\end{array}$ & $\begin{array}{l}-0.007 \\
(-0.09)\end{array}$ \\
\hline$(\ln \text { land })^{2}$ & $\begin{array}{l}-0.06 * * * \\
(-2.82)\end{array}$ & & $\begin{array}{l}-0.05^{* *} \\
(-2.50)\end{array}$ & \\
\hline$(\ln l a b o r)^{2}$ & $\begin{array}{l}-.06 * * * \\
(-3.26)\end{array}$ & & $\begin{array}{l}-0.06 * * * \\
(-2.79)\end{array}$ & \\
\hline$(\ln \text { fallow })^{2}$ & $\begin{array}{l}0.004 \\
(0.05)\end{array}$ & & $\begin{array}{l}0.10 \\
(1.36)\end{array}$ & \\
\hline$($ ln fallow $) *(\ln$ land $)$ & $\begin{array}{l}-0.005 \\
(0.11)\end{array}$ & & $\begin{array}{l}-0.08 \\
(-1.13)\end{array}$ & \\
\hline$($ ln fallow $) *(\ln$ labor $)$ & $\begin{array}{l}0.03 \\
(0.51)\end{array}$ & & $\begin{array}{l}0.02 \\
(0.20)\end{array}$ & \\
\hline$(\ln l a n d) *(\ln$ labor $)$ & $\begin{array}{l}0.03 \\
(0.65)\end{array}$ & & $\begin{array}{l}0.03 \\
(0.56)\end{array}$ & \\
\hline constant & $\begin{array}{l}2.35 \\
(0.67)\end{array}$ & $\begin{array}{l}7.08 \\
(12.04)\end{array}$ & $\begin{array}{l}2.43 \\
(0.63)\end{array}$ & $\begin{array}{l}7.37 \\
(12.22)\end{array}$ \\
\hline$N$ & 365 & 365 & 337 & 337 \\
\hline$R^{2}$ & .63 & .59 & .61 & .57 \\
\hline
\end{tabular}

*sig. at $90 \%$ confidence level; $* *$ sig. at $95 \% ; * * *$ sig. at $99 \%$

Table 4B: Stochastic Frontier Production Function Results (z-values reported in parentheses; village dummies were included in all specifications, but are not reported in table)

\begin{tabular}{|c|c|c|c|c|c|c|c|}
\hline \multicolumn{8}{|l|}{$\begin{array}{l}\text { Dependent Variable: } \\
\text { log harvest value }\end{array}$} \\
\hline & $\begin{array}{l}\text { Model I: } \\
\text { SFP }\end{array}$ & & & & $\begin{array}{l}\text { Model II: } \\
\text { SNN FP }\end{array}$ & & \\
\hline & TL & CD & TL & CD & TL & CD 'fal1' & CD \\
\hline & 'fal1' & 'fal1' & 'fal2' & 'fal2' & 'fal1' & & 'fal2' \\
\hline In land & $\begin{array}{l}1.12 * * * \\
(3.08)\end{array}$ & $\begin{array}{l}0.21 * * * \\
(6.09)\end{array}$ & $\begin{array}{l}1.09 * * * \\
(2.73)\end{array}$ & $\begin{array}{l}0.19 * * * \\
(5.61)\end{array}$ & $\begin{array}{l}0.63 \\
(1.58)\end{array}$ & $\begin{array}{l}0.21 * * * \\
(5.84)\end{array}$ & $\begin{array}{l}0.21 * * * \\
(6.27)\end{array}$ \\
\hline In labor & $\begin{array}{l}0.81 * * \\
(1.90)\end{array}$ & $\begin{array}{l}0.62 * * * \\
(13.95)\end{array}$ & $\begin{array}{l}0.69 \\
(1.31)\end{array}$ & $\begin{array}{l}0.61 * * * \\
(12.57)\end{array}$ & $\begin{array}{l}0.19 \\
(1.36)\end{array}$ & $\begin{array}{l}0.45 * * * \\
(8.84)\end{array}$ & $\begin{array}{l}0.45^{* * *} \\
(8.56)\end{array}$ \\
\hline In fallow & $\begin{array}{l}-0.03 \\
(-0.04)\end{array}$ & $\begin{array}{l}0.03 \\
(0.52)\end{array}$ & $\begin{array}{l}0.15 \\
(0.19)\end{array}$ & $\begin{array}{l}0.03 \\
(0.38)\end{array}$ & $\begin{array}{l}-0.30 \\
(0.44)\end{array}$ & $\begin{array}{l}0.05 \\
(0.90)\end{array}$ & $\begin{array}{l}0.06 \\
(0.78)\end{array}$ \\
\hline land $^{2}$ & $\begin{array}{l}-0.06 * * * \\
(-3.61)\end{array}$ & & $\begin{array}{l}-0.05 * * * \\
(-2.91)\end{array}$ & & $\begin{array}{l}-0.04 * * \\
(-2.53)\end{array}$ & & \\
\hline labor ${ }^{2}$ & $\begin{array}{l}-0.06 * * * \\
(-4.49)\end{array}$ & & $\begin{array}{l}-0.06 * * * \\
(-3.91)\end{array}$ & & $\begin{array}{l}-0.05 * * * \\
(-4.02)\end{array}$ & & \\
\hline fallow $^{2}$ & -0.01 & & $0.10^{*}$ & & -0.02 & & \\
\hline
\end{tabular}




\begin{tabular}{|c|c|c|c|c|c|c|c|}
\hline \multirow{3}{*}{ land*labor } & \multicolumn{2}{|l|}{$(-0.13)$} & \multicolumn{2}{|l|}{$(1.79)$} & \multicolumn{3}{|l|}{$(-0.22)$} \\
\hline & 0.03 & & 0.03 & & $0.07 *$ & & \\
\hline & $(0.93)$ & & $(0.87)$ & & $(1.70)$ & & \\
\hline land ${ }^{*}$ fallow & -0.004 & & -0.08 & & -0.009 & & \\
\hline labor*fallow & $\begin{array}{l}(-0.09) \\
0.03 \\
(0.93)\end{array}$ & & $\begin{array}{l}(-1.44) \\
0.05 \\
(0.46)\end{array}$ & & $\begin{array}{l}(-0.18) \\
0.09 \\
(1.15)\end{array}$ & & \\
\hline constant & $\begin{array}{l}3.14 \\
(1.10)\end{array}$ & $\begin{array}{l}7.74 \\
(19.44)\end{array}$ & $\begin{array}{l}3.50 \\
(1.04)\end{array}$ & $\begin{array}{l}7.92 \\
(18.19)\end{array}$ & $\begin{array}{l}7.77 \\
(2.29)\end{array}$ & $\begin{array}{l}8.26 \\
(20.28)\end{array}$ & $\begin{array}{l}8.13 \\
(19.57)\end{array}$ \\
\hline$N$ & 365 & 365 & 337 & 337 & 365 & 365 & 337 \\
\hline Wald $\chi^{2}$ & 665.94 & 510.55 & 584.52 & 434.93 & 386.19 & 354.68 & 367.80 \\
\hline$\left(\right.$ prob $\left.>\chi^{2}\right)$ & $(0.00)$ & $(0.00)$ & $(0.00)$ & $(0.00)$ & $(0.00)$ & $(0.00)$ & $(0.00)$ \\
\hline log likelihood & -281.00 & -295.77 & -257.25 & -271.99 & -259.50 & -261.03 & -235.70 \\
\hline $\begin{array}{l}\text { TE (mean with std. } \\
\text { dev in parentheses) }\end{array}$ & $\begin{array}{l}0.67 \\
(0.13)\end{array}$ & $\begin{array}{l}0.63 \\
(0.15)\end{array}$ & $\begin{array}{l}0.67 \\
(0.13)\end{array}$ & $\begin{array}{l}0.63 \\
(0.15)\end{array}$ & $\begin{array}{l}0.71 \\
(0.14)\end{array}$ & $\begin{array}{l}0.94 \\
(0.15)\end{array}$ & $\begin{array}{l}0.96 \\
(0.15)\end{array}$ \\
\hline LR test $\sigma u=0$ & 4.12 & 7.44 & 4.28 & 7.26 & & & \\
\hline prob $>\overline{\chi^{2}}(1)$ & $(0.02)$ & $(\Omega \cap \cap)$ & $(0.02)$ & $(0.00)$ & & & \\
\hline $\begin{array}{l}\text { LR test } C D \text { is adequate } \\
\text { representation of techno. }\end{array}$ & & $\begin{array}{l}29.54 \\
(0.00)\end{array}$ & & $\begin{array}{l}29.50 \\
(0.00)\end{array}$ & & $\begin{array}{l}3.06 \\
(0.80)\end{array}$ & \\
\hline
\end{tabular}

Table 4C: Determinants of Technical Efficiency for Model 2

Dependent Variable:

technical inefficiency

\begin{tabular}{|c|c|c|c|}
\hline & $\begin{array}{l}\text { TL } \\
\text { 'fal1' }\end{array}$ & $\begin{array}{l}\text { CD } \\
\text { 'fal1' }\end{array}$ & $\begin{array}{l}\text { CD } \\
\text { 'fal2' }\end{array}$ \\
\hline \multicolumn{4}{|l|}{ Farmer Characteristics } \\
\hline Age of male & $\begin{array}{l}-0.06 \\
(-0.42)\end{array}$ & $\begin{array}{l}0.37 \\
(0.97)\end{array}$ & $\begin{array}{l}0.21 \\
(0.24)\end{array}$ \\
\hline Age of female & $\begin{array}{l}0.09 \\
(0.54)\end{array}$ & $\begin{array}{l}-0.47 \\
(-0.95)\end{array}$ & $\begin{array}{l}-1.27 \\
(-1.95)\end{array}$ \\
\hline $\begin{array}{l}\text { Yrs of education of } \\
\text { head hh }\end{array}$ & $\begin{array}{l}0.16 \\
(0.32)\end{array}$ & $\begin{array}{l}-0.96 \\
(-0.55)\end{array}$ & $\begin{array}{l}-1.41 \\
(-0.51)\end{array}$ \\
\hline Gender of head of hh & $\begin{array}{l}3.67 \\
(0.58)\end{array}$ & $\begin{array}{l}-4.47 \\
(-0.19)\end{array}$ & $\begin{array}{l}-37.41 \\
(-1.05)\end{array}$ \\
\hline $\begin{array}{l}\text { Primary activity of male } \\
(1=\text { agriculture }) \\
\text { Prim. activity of female } \\
(1=\text { agriculture })\end{array}$ & $\begin{array}{l}-5.15 \\
(-0.90) \\
0.11 \\
(0.03)\end{array}$ & $\begin{array}{l}\mathbf{- 3 5 . 0 2} * * \\
(-\mathbf{2 . 0 8}) \\
1.01 \\
(0.12)\end{array}$ & $\begin{array}{l}-40.02 \\
(-1.01) \\
10.12 \\
(0.59)\end{array}$ \\
\hline \multicolumn{4}{|l|}{ Interaction terms } \\
\hline Age male * land & $\begin{array}{l}0.02 \\
(1.28)\end{array}$ & $\begin{array}{l}0.07 \\
(1.44)\end{array}$ & $\begin{array}{l}0.05 \\
(0.59)\end{array}$ \\
\hline Age male * labor & $\begin{array}{l}-0.02 \\
(-0.82)\end{array}$ & $\begin{array}{l}-0.20^{*} \\
(-1.94)\end{array}$ & $\begin{array}{l}-0.23 \\
(-1.29)\end{array}$ \\
\hline Age male * fallow & $\begin{array}{l}-0.02 \\
(-0.62)\end{array}$ & $\begin{array}{l}0.02 \\
(0.26)\end{array}$ & $\begin{array}{l}0.25 \\
(1.19)\end{array}$ \\
\hline Age female *land & $\begin{array}{l}-0.02 \\
(-1.08)\end{array}$ & $\begin{array}{l}-0.11^{*} \\
(-1.72)\end{array}$ & $\begin{array}{l}-0.11 \\
(-0.99)\end{array}$ \\
\hline Age female * labor & $\begin{array}{l}0.02 \\
(0.67)\end{array}$ & $\begin{array}{l}0.34 * \\
(1.84)\end{array}$ & $\begin{array}{l}0.41 \\
(1.52)\end{array}$ \\
\hline Age female * fallow & 0.009 & -0.08 & -0.25 \\
\hline
\end{tabular}




\begin{tabular}{|c|c|c|c|}
\hline & $(0.28)$ & $(-0.74)$ & $(-1.27)$ \\
\hline Yrs edu *land & $\begin{array}{l}-0.008 \\
(-0.19)\end{array}$ & $\begin{array}{l}0.25^{*} \\
(1.68)\end{array}$ & $\begin{array}{l}0.61^{*} \\
(186)\end{array}$ \\
\hline Yrs edu*labor & $\begin{array}{l}-0.05 \\
(-0.93)\end{array}$ & $\begin{array}{l}-0.86 * * \\
(-2.69)\end{array}$ & $\begin{array}{l}-1.80^{*} \\
(-1.78)\end{array}$ \\
\hline Yrs edu * fallow & $\begin{array}{l}0.13 \\
(1.53)\end{array}$ & $\begin{array}{l}1.17 * * \\
(2.17)\end{array}$ & $\begin{array}{l}1.66 \\
(1.58)\end{array}$ \\
\hline Gender * land & $\begin{array}{l}-0.62 \\
(-1.13)\end{array}$ & $\begin{array}{l}4.01 * \\
(1.92)\end{array}$ & $\begin{array}{l}7.09 \\
(1.46)\end{array}$ \\
\hline Gender * labor & $\begin{array}{l}0.50 \\
(0.52)\end{array}$ & $\begin{array}{l}-5.10 \\
(-1.26)\end{array}$ & $\begin{array}{l}-4.93 \\
(-0.90)\end{array}$ \\
\hline Gender $*$ fallow & $\begin{array}{l}-0.73 \\
(-0.78)\end{array}$ & $\begin{array}{l}-1.02 \\
(-0.39)\end{array}$ & $\begin{array}{l}1.03 \\
(0.32)\end{array}$ \\
\hline PA male * land & $\begin{array}{l}0.79 \\
(1.37)\end{array}$ & $\begin{array}{l}7.26 * * * \\
(2.64)\end{array}$ & $\begin{array}{l}10.85 \\
(1.36)\end{array}$ \\
\hline PA male*labor & $\begin{array}{l}0.46 \\
(1.12)\end{array}$ & $\begin{array}{l}-3.24 * * \\
(-2.32)\end{array}$ & $\begin{array}{l}-9.55 \\
(-1.41)\end{array}$ \\
\hline PA male *fallow & $\begin{array}{l}0.80 \\
(0.85)\end{array}$ & $\begin{array}{l}-7.32 * \\
(-1.72)\end{array}$ & $\begin{array}{l}-4.29 \\
(-0.41)\end{array}$ \\
\hline PA fem*land & $\begin{array}{l}-0.38 \\
(-1.11)\end{array}$ & $\begin{array}{l}-1.87^{*} \\
(-1.85)\end{array}$ & $\begin{array}{l}-3.78 \\
(-1.36)\end{array}$ \\
\hline PA fem*labor & $\begin{array}{l}0.46 \\
(1.12)\end{array}$ & $\begin{array}{l}1.55 \\
(1.59)\end{array}$ & $\begin{array}{l}1.64 \\
(1.36)\end{array}$ \\
\hline PA fem $*$ fallow & $\begin{array}{l}-0.02 \\
(-0.03)\end{array}$ & $\begin{array}{l}0.22 \\
(0.13)\end{array}$ & $\begin{array}{l}-0.06 \\
(-0.01)\end{array}$ \\
\hline constant & $\begin{array}{l}-2.04 \\
(1.94)\end{array}$ & $\begin{array}{l}8.87 \\
(1.96)\end{array}$ & $\begin{array}{l}32.26 \\
(1.63)\end{array}$ \\
\hline
\end{tabular}

